\title{
Basin Analysis of the Mississippi Interior Salt Basin and Petroleum System Modeling of the Jurassic Smackover Formation, Eastern Gulf Coastal Plain
}

\author{
Quarterly Report \\ April 1 - June 30, 1998
}

\author{
By: \\ Ernest A. Mancini
}

Work Performed Under Contract No.: DE-FG22-96BC14946

\author{
For \\ U.S. Department of Energy \\ Office of Fossil Energy \\ Federal Energy Technology Center \\ P.O. Box 880 \\ Morgantown, West Virginia 26507-0880
}

By

University of Alabama

Department of Geology

P. O. Box 870338

202 Bevill Building

Tuscaloosa, Alabama 35487-0338 


\section{Disclaimer}

This report was prepared as an account of work sponsored by an agency of the United States Government. Neither the United States Government nor any agency thereof, nor any of their employees, makes any warranty, express or implied, or assumes any legal liability or responsibility for the accuracy, completeness, or usefulness of any information, apparatus, product, or process disclosed, or represents that its use would not infringe privately owned rights. Reference herein to any specific commercial product, process, or service by trade

name, trademark, manufacturer, or otherwise does not necessarily constitute or imply its endorsement, recommendation, or favoring by the United States Government or any agency thereof. The views and opinions of authors expressed herein do not necessarily state or reflect those of the United States Government or any agency thereof. 


\section{Report Title}

"Basin Analysis of the Mississippi Interior Salt Basin and Petroleum System Modeling of the Jurassic Smackover Formation, Eastern Gulf Coastal Plain"

\section{Type of Report}

Third Quarterly Progress Report for Year 2

\section{Reporting Period Start Date}

August 23, 1997

\section{Reporting Period End Date}

June 30, 1998

\section{Principal Author}

Ernest A. Mancini (205/348-4319)

Department of Geology

Box 870338

202 Bevill Building

University of Alabama

Tuscaloosa, AL 35487-0338

\section{Date Report was Issued}

July 7, 1998

DOE Award Number

DE-FG22-96BC14946--08

\section{Disclaimer}

This report was prepared as an account of work sponsored by an agency of the United States Government. Neither the United States Government nor any agency thereof, nor any of their employees, makes any warranty, express or implied, or assumes any legal liability or responsibility for the accuracy, completeness, or usefulness of any information, apparatus, product, or process disclosed, or represents that its use would not infringe privately owned rights. Reference herein to any specific commercial product, 
process, or service by trade name, trademark, manufacturer, or otherwise does not necessarily constitute or imply its endorsement, recommendation, or favoring by the United States Government or any agency thereof. The views and opinions of authors expressed herein do not necessarily state or reflect those of the United States Government or any agency thereof. 


\section{"Basin Analysis of the Mississippi Interior Salt Basin and Petroleum System Modeling of the Jurassic Smackover Formation, Eastern Gulf Coastal Plain"}

Third Quarterly Report for Year 2

April 1, 1998_June 30, 1998

\section{Project Objectives}

Part 2 (Basin Analysis of the Mississippi Interior Salt Basin) objectives are to provide a comprehensive analysis of the Mississippi Interior Salt Basin in Years 2 and 3 of the project and to transfer effectively the research results to producers through workshops and topical reports.

\section{Work Accomplished}

\section{Task 1-Tectonic History}

The regional base map for the oil and gas fields, land grid map, field and reservoir productivity tabulation and well location and formation top database have been prepared. The well database consists of over 3,000 oil and gas wells that penetrated Jurassic strata in the Mississippi Interior Salt Basin area. Subsurface structure maps and isopach maps have been constructed on key stratigraphic horizons. The structure maps and isopach maps have been compared to reconstruct the tectonic history of the basin. The 48 wells for the five regional cross sections have been selected and interpreted and the cross sections have been drawn.

\section{Task 2-Depositional History}

The biostratigraphy/stratigraphy for the selected well has been completed. The well logs for the regional cross sections have been interpreted. The isopach maps have been compared for reconstruction of the basin history.

\section{Task 3-Burial History}

Standard burial and thermal history software has been acquired. Profiles for the 48 wells used in the cross sections are being modeled using this software to determine the burial history of the basin. Sedimentation and subsidence rate determinations are being made for these wells. 


\section{Task 4-Thermal History}

Oil and source rock analysis data have been tabulated and the distribution of the data are being plotted on the regional base map. Select well samples have been examined to assess the amount of organic matter available for vitrinite reflectance study of kerogen for crucial stratigraphic intervals. This study produced limited results. Geothermal gradient and heat flow data from the literature for the basin have been evaluated. Thermal alteration indices in combination with bottomhole temperature data are being used in combination with the results of the vitrinite reflectance study to determine geothermal gradients.

\section{Task 5-Technology Transfer}

Planning workshops were held in Tuscaloosa, Alabama, on September 26, 1997, and in Jackson, Mississippi, on November 6, 1997, to discuss with producers the research plan for Part 2 of the project. The recommendations received at the workshops have been incorporated into the research plan. Technology transfer workshops focusing on carbonate reservoir characterization and modeling were held in Tuscaloosa, Alabama, on March 3, 1998, and in Jackson, Mississippi, on March 4, 1998.

The first year report, field production data, and a case history study of the Smackover Formation at Appleton Field have been posted on the website of the Eastern Gulf Region of the Petroleum Technology Transfer Council.

\section{Work Planned}

\section{Task 1-Tectonic History}

Interpretation of the tectonic history of the basin will continue to be made from the structure and isopach maps and regional cross sections.

\section{Task 2-Depositional History}

Sequence stratigraphic analysis will continue. Interpretation of the depositional history of the basin will continue to be made utilizing the isopach maps, regional cross sections, well cuttings/core descriptions from the wells, and sequence stratigraphic analysis.

\section{Task 3-Burial History}

Interpretation of the burial histories for the 48 wells selected for the regional cross sections will be finalized. Sedimentation and subsidence rate determinations will be completed. 


\section{Task 4-Thermal History}

Interpretation of the thermal histories for the 48 wells selected for the regional cross sections will be finalized. Geothermal gradient, heat flow, and subsurface temperature grid constructions will be completed.

\section{Task 5-Technology Transfer}

Planning for the workshops on the tectonic and depositional history and the burial and thermal history of the basin will be completed. The workshops will be held early in 1999.

\section{Task 6-Topical Reports}

Report preparation will continue. Topical reports (2) on the tectonics and depositional history and the burial and thermal history of the basin will be completed by October 1, 1998. 


\section{Research Plan}

\section{Regional Basin Analysis}

Time Frame

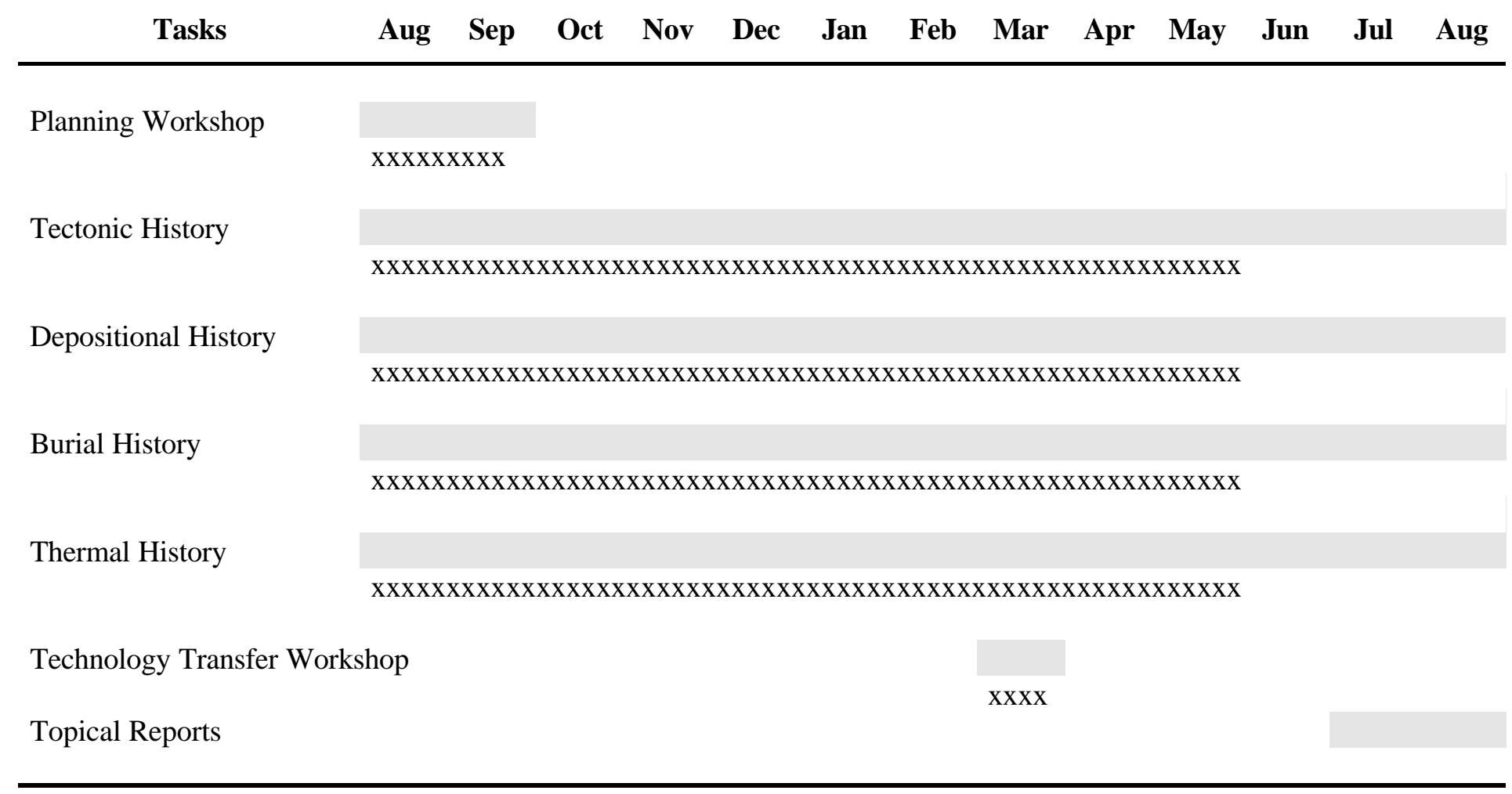

Planned

Completed $\quad \mathrm{xxxx}$ 